\title{
PENGARUH MODEL PEMBELAJARAN KOOPERATIF TIPE THINK PAIR SHARE (TPS) TERHADAP PENINGKATAN KEMAMPUAN PEMECAHAN MASALAH MATEMATIS SISWA
}

\author{
TELA,VARA NINA YULIAN, YANRY BUDIANINGSIH \\ PENDIDIKAN MATEMATIKA FKIP UNIVERSITAS SUBANG
}

\section{Tela_matematika@yahoo.com}

\begin{abstract}
ABSTRAK
Penelitian ini dilatar belakangi oleh kurangnya kemampuan pemecahan masalah matematis siswa. Hal ini salah satunya dipengaruhi oleh model pembelajaran yang digunakan. Model pembelajaran yang dapat membantu siswa dalam pemecahan masalah yaitu model pembelajaran kooperatif tipe think pair share (TPS). Tujuan penelitian ini adalah: 1) Untuk mengetahui peningkatan kemampuan pemecahan masalah matematis siswa dengan model pembelajaran kooperatif tipe Think Pair Share (TPS) lebih baik dari pada pembelajaran ekspositori; 2) Untuk mengetahui pengaruh model pembelajaran kooperatif tipe Think Pair Share (TPS) terhadap peningkatan kemampuan pemecahan masalah matematis siswa. Metode yang digunakan dalam penelitian ini adalah metode studi kuasi eksperimen dan lokasi penelitian ini adalah SMPIT Asyifa Boarding School. Dengan Subjek penelitian siswa kelas VII Fatimah sebagai kelas eksperimen dan VII Maryam sebagai kelas kontrol. Hasil penelitian menunjukan bahwa: 1) Peningkatan kemampuan pemecahan masalah matematis siswa dengan model pembelajaran kooperatif tipe Think Pair Share (TPS) lebih baik dibandingkan dengan pembelajaran ekspositori; 2) Model pembelajaran kooperatif tipe Think Pair Share (TPS) berpengaruh terhadap peningkatan kemampuan pemecahan masalah matematis siswa.
\end{abstract}

Kata kunci : Think Pair Share (TPS), Kemampuan Pemecahan Masalah Matematis.

\section{PENDAHULUAN}

Undang - Undang No 20 tahun 2013 tentang Sistem Pendidikan Nasional menyatakan bahwa "pendidikan adalah usaha sadar dan terencana untuk mewujudkan suasana belajar dan proses pembelajaran untuk memiliki kekuatan spiritual keagamaan, pengendalian diri, kepribadian, kecerdasan, akhlak mulia serta keterampilan yang diperlukan dirinya masyarakat bangsa dan Negara".

Pendidikan adalah usaha sadar dan terencana hal ini berarti proses pendidikan di sekolah mempunyai tujuan sehingga segala sesuatu yang dilakukan guru dan siswa diarahkan pada suatu pencapaian tujuan. Proses pendidikan yang terencana itu diarahkan untuk mewujudkan suasana belajar dan proses pembelajaran, hal ini berarti pendidikan tidak boleh mengesampingkan proses belajar. Suasana belajar dan 
pembelajaran diarahkan agar peserta didik dapat mengembangkan potensi dirinya, ini berarti pendidikan itu harus berorientasi kepada siswa dan pendidikan merupakan upaya mengembangkan potensi anak didik (Sanjaya, $2013: 2$ ).

Akhir dari proses pendidikan adalah kemampuan anak memiliki kemampuan spiritual keagamaan, pengendalian diri, kepribadian, kecerdasan, akhlak mulia, serta keterampilan yang diperlukan dirinya, masyarakat, bangsa, dan Negara.

Dengan demikian pendidikan adalah suatu upaya yang dilakukan oleh pendidik guna mengembangkan suatu potensi kemampuan peserta didik yang memiliki kekuatan spiritual keagamaan, pengendalian diri, kepribadian, kecerdasan, akhlak mulia, serta keterampilan yang diperlukan baik dirinya masyarakat bangsa dan negara yang pada akhirnya tercapai suatu kebahagiaan dan menjadi manusia yang tumbuh dan berkembang dengan baik.

Pendidikan tidak terlepas dari proses belajar salah satunya adalah belajar matematika. Matematika adalah salah satu ilmu yang mendasari perkembangan ilmu pengetahuan dan teknologi sehingga perlu di berikan kepada semua jenjang pendidikan diantaranya dari SD sampai dengan SMA. Menurut Rahmawati (2016) hasil studi yang dilakukan oleh program internasional yaitu PISA (Program For International Student Assessment) yaitu studi yang memfokuskan pada literasi bacaan, matematika menyatakan bahwa Indonesia mendapat rangking untuk sains 62, matematika 63, dan membaca 64 dari 70 negara sementara hasil yang dilakukan studi TIMSS (Trend In International Mathematics dan Sciencs Study) menunjukan ranging sangat rendah dalam beberapa kemampuan diantaranya : (1) memahami informasi yang kompleks (2) teori analisis dan pemecahan masalah (3) pemakaian alat, prosedur, pemecahan masalah (4) melakukan investigasi terhadap suatu masalah.

Hasil studi ini menunjukan perlu ada perubahan pada aspek kemampuan salah satunya pemecahan masalah. Masalah (problem) merupakan bagian dari kehidupan manusia baik bersumber dari dalam maupun dari lingkungan sekitar (Hartono: 2014). Setiap kehidupan penuh dengan masalah sehingga lahirlah suatu pemecahan masalah

guna menyelesaikan hal tersebut begitupun dengan soal matematika. Di dukung dengan tujuan umum pembelajaran matematika yang telah disusun oleh pemerintah melalui Badan Standar Nasional Pendidikan (BNSP, 2006) yang tertuang dalam Permendiknas No 22 Tahun 2016, yaitu agar siswa memiliki kemampuan.

1. Memahami konsep matematika, menjelaskan keterkaitan antara konsep dan pengaplikasikan konsep atau algoritma secara luwes, akurat, efisien, dan tepat dalam pemecahan masalah.

2. Mengunakan penalaran pada pola dan sifat, melakukan manipulasi matematika dalam membuat generalisasi, menyusun bukti atau menjelaskan gagasan dan pernyataan matematika.

3. Memecahkan masalah yang meliputi kemampuan memahami masalah, merancang model matematika, menyelesaikan model, dan menafsirkan solusi yang diperoleh. 
4. Mengomunikasikan gagasan dengan simbol, tabel, diagram, atau media lain untuk memperjelas keadaan atau masalah.

5. Memiliki sikap menghargai kegunaan matematika dalam kehidupan yaitu rasa ingin tahu, perhatian dan minat dalam pempelajari matematika serta sikap ulet dan percaya diri dalam pemecahan masalah.

Berdasarkan uraian di atas kemampuan pemecahan masalah merupakan salah satu tujuan umum matematika sehingga pemecahan masalah matematis memiliki peranan sangat penting dan jika tujuan di atas dilaksanakan dengan baik maka akan meningkatkan mutu pendidikan.

Kemampuan pemecahan masalah matematis perlu dimiliki siswa, oleh karena itu pembelajaran matematika perlu diperbaharui guna meningkatkan pemecahan masalah matematis dengan cara menerapkan model pembelajaran kooperatif tipe Think Pair Share (TPS). Model pembelajaran kooperatif tipe think pair share (TPS) merupakan jenis pembelajaran kooperatif yang dirancang untuk mempengaruhi pola interaksi siswa pertama kali diperkenalkan oleh Frank Lyman dkk tahun 1985 di University of Maryland.

Model pembelajaran Think Pair Share dapat meningkatkan kemampuan pemecahan masalah pendapat ini didukung oleh hasil peneliti yang telah dilakukan Sujana (2017) dengan judul penerapan model pembelajaran kooperatif tipe Think Pair Share untuk meningkatkan kemampuan pemecahan masalah matematika siswa di SMP Negeri Satap 5 Banjarsari pada kelas VIII, menyatakan bahwa data kemampuan pemecahan masalah matematika kelas eskperimen lebih tinggi dari pada kelas kontrol.

Kelebihan dari model pembelajaran kooperatif tipe Think Pair Share (TPS) memberikan siswa waktu untuk berpikir dan merespon serta saling bantu satu sama lain sehingga kemampuan pemecahan masalah akan di peroleh dengan baik, dan keterampilan sosial pun akan tumbuh manakala aspek TPS di terapkan yaitu aspek bertanya, aspek menyampaikan ide atau pendapat dan keterampilan sosial aspek bekerjasama. Komponen Think Pair Share (TPS) yaitu ada tiga tahap, Think (berpikir), Pair (perpasangan), dan Share (berbagi), dalam tahap Think yang artinya berfikir proses pemecahan masalah akan di dapat.

\section{METODE PENELITIAN}

Metode yang digunakan dalam penelitian ini adalah penelitian quasi eksperimen. dengan pembelajaran menggunakan model pembelajaran kooperatif tipe think pair share (TPS) sebagai variabel bebas dan variabel terikatnya adalah kemampuan pemecahan masalah matematis siswa.

Desain yang digunakan adalah desain the nonequivalent pretest-postest control grup design dimana dalam penelitian ini terdapat dua kelompok yaitu kelompok eksperimen dan kelompok kontrol. Menurut Sugiyono (2015) sampel adalah bagian dari jumlah dan karakteristik yang dimiliki oleh populasi. Dalam peneliti pengambilan sampel dilakukan dengan teknik Cluster Random Sampling, yaitu pengambilan 2 unit kelas dari empat kelas pada populasi. Sehingga didapat satu kelas bertindak sebagai kelas eksperimen dan satu kelas lagi bertindak sebagai kelas kontrol. Adapun kelas 
yang terpilih adalah kelas VII Fatimah sebagai kelas eksperimen dan VII Maryam sebagai kelas kontrol. Kelas eksperimen adalah kelompok siswa yang mendapatkan perlakuan dengan model pembelajaran kooperatif tipe Think Pair Share (TPS) sedangkan kelas kontrol adalah kelompok siswa yang mendapatkan pembelajaran ekspositori dengan jumlah siswa masing - masing kelas eksperimen dan kontrol adalah 30 siswa

\section{HASIL DAN PEMBAHASAN}

Data diperoleh melalui tes kemampuan pemecahan masalah matematis siswa SMPIT Asyifa Boarding School. Data yang digunakan untuk menghitung peningkatan kemampuan pemecahan masalah matematis siswa adalah data nilai gain dan untuk pengaruh menggunakan effect size.

\section{HASIL PENELITIAN}

1. Analisis peningkatan kemampuan pemecahan masalah matematis siswa Hasil analisis data peningkatan kemampuan pemecahan masalah matematis siswa kelas eksperimen dan kelas control terdiri dari data pretes, data uji normalitas dan data uji dua rerata yang tertuang pada tabel berikut ini :

Tabel 1. Deskripsi Nilai Pretes dan Postes Kemampuan Pemecahan Masalah Matematis

\begin{tabular}{|c|c|c|c|}
\hline Tes & $\mathrm{N}$ & Kelas eksperimen & Kelas kontrol \\
\hline Pretes & 30 & 5,74 & 5,67 \\
\hline Postes & 30 & 8,04 & 7,09 \\
\hline
\end{tabular}

Berdasarkan tabel 1 diatas terlihat bahwa rata- rata skor pretes kelas eksperimen 5,74 sedangkan kelas kontrol 5,67. Sedangkan rata - rata skor postes kelas eksperimen 8,04 dan kelas kontrol 7,09. Uji statistic yang digunakan adalah uji normalitas, homogenitas dan uji dua rerata.

Berikut hasil uji normalitas skor pretes dan postes kemampuan pemecahan masalah matematis siswa sebagai berikut :

Tabel 2. Uji normalitas Skor Pretes dan Postes Kemampuan Pemecahan Masalah Matematis

\begin{tabular}{|c|l|c|}
\hline Hasil & \multicolumn{1}{|c|}{ Kelas } & Sig. \\
\hline \multirow{2}{*}{ Pretes } & Eksperimen & 0,074 \\
\cline { 2 - 3 } & Kontrol & 0,0434 \\
\hline \multirow{2}{*}{ Postes } & Eksperimen & 0,682 \\
\cline { 2 - 3 } & Kontrol & 0,245 \\
\hline
\end{tabular}


Berdasarkan tabel 2 diatas maka dapat disimpulkan bahwa data berdistribusi normal, maka selanjutnya dilakukan uji homogenitas. Berikut hasil pengujian uji homogenitas dapat dilihat berikut ini :

Tabel 3. Uji Homogenitas Skor Pretes Postes kemampuan Pemecahan Masalah Matematis

\begin{tabular}{|c|l|c|}
\hline Hasil & \multicolumn{1}{|c|}{ Kelas } & Sig. \\
\hline \multirow{2}{*}{ Pretes } & Eksperimen & \multirow{2}{*}{0.387} \\
\cline { 2 - 3 } & Kontrol & \\
\hline \multirow{2}{*}{ Postes } & Eksperimen & \multirow{2}{*}{0,619} \\
\cline { 2 - 2 } & Kontrol & \\
\hline
\end{tabular}

Berdasarkan tabel 3 diatas terlihat bahwa nilai signifikansi kelas eksperimen dan kelas kontrol lebih besar dari 0,05 artinya sampel kedua varians sama, selanjutnya dilakukan uji dua rerata dengan uji - t. Berikut hasil uji dua rerata dapat dilihat pada tabel dibawah ini:

Tabel 4. Hasil Uji Dua Rerata Pretes dan Postes kemampuan Pemecahan Masalah Matematis

\begin{tabular}{|c|l|c|}
\hline Hasil & \multicolumn{1}{|c|}{ Kelas } & Sig. \\
\hline \multirow{2}{*}{ Pretes } & Eksperimen & 0,793 \\
\cline { 2 - 3 } & Kontrol & 0,793 \\
\hline \multirow{2}{*}{ Postes } & Eksperimen & 0,000 \\
\cline { 2 - 3 } & Kontrol & 0,000 \\
\hline
\end{tabular}

Berdasarkan tabel 4 diatas terlihat bahwa pada pretes nilai signifikansi nilai eksperimen dan kelas kontrol lebih besar dari 0,05 artinya data pretes siswa kelas eksperimen yang mendapat pembelajaran dengan model pembelajaran kooperatif tipe Think Pair Share (TPS) dan siswa kelas kontrol yang mendapat pembelajaran dengan menggunakan pembelajaran ekspositori tidak ada perbedaan rata - rata. Sedangkan pada postes nilai signifikansi kelas eksperimen dan kelas kontrol lebih kecil dari 0,05 artinya data postes kelas eksperimen dengan menggunakan model pembelajaran kooperatif tipe Think Pair Share (TPS) dan siswa kelas kontrol yang menggunakan pembelajaran ekspositori memiliki perbedaan rata - rata.

Untuk mengetahui peningkatan kemampuan pemecahan masalah matematis siswa dengan model pembelajaran Think Pair Share (TPS) lebih baik dari pada pembelajaran ekspositori menggunakan perhitungan indeks gain. Berikut hasil uji dua rerata dapat dilihat pada tabel dibawah ini: 
Tabel 5. Deskripsi Indeks Gain Kemampuan Pemecahan Masalah Matematis

\begin{tabular}{|c|c|c|c|c|c|c|}
\hline \multirow[b]{2}{*}{ Kelas } & \multirow[b]{2}{*}{$\mathrm{N}$} & \multirow{2}{*}{$\begin{array}{l}\text { Rerata Skor } \\
\text { Indeks Gain }\end{array}$} & \multicolumn{2}{|c|}{ Uji Normalitas } & \multicolumn{2}{|c|}{ Uji Mann - Whitney } \\
\hline & & & $\begin{array}{l}\text { Shapiro } \\
\text { - Wilk }\end{array}$ & Ket & $\begin{array}{l}\text { Asym. Sig } \\
(2-\text { tailed })\end{array}$ & Ket \\
\hline $\begin{array}{l}\text { Eksperimen } \\
\text { (Model TPS) }\end{array}$ & 30 & 0,55 & 0,55 & \multirow{2}{*}{$\begin{array}{l}\text { Tidak } \\
\text { Normal }\end{array}$} & \multirow{2}{*}{0,000} & \multirow{2}{*}{$\begin{array}{l}\text { Terdapat } \\
\text { perbedaan } \\
\text { yang } \\
\text { signifikan }\end{array}$} \\
\hline $\begin{array}{l}\text { Kontrol } \\
\text { (ekspositori) }\end{array}$ & 30 & 0,33 & 0,00 & & & \\
\hline
\end{tabular}

Berdasarkan tabel 5 diatas terlihat bahwa nilai signifikansi uji normalitas kelas eksperimen 0,55 lebih dari 0,05 sedangkan kelas kontrol 0,00 kurang dari 0,05 maka data berdiistribusi tidak normal selanjutnya dilakukan uji mann - whitney.

Dari tabel 5 diatas terlihat bahwa nilai signifikansi uji mann - whitney adalah 0,000 karena 0,000 kurang dari 0,05 artinya peningkatan kemampuan pemecahan masalah matematis siswa dengan model pembelajran kooperatif tipe Think Pair Share (TPS) lebih baik dibandingkan dengan pembelajaran ekspositori.

Effect size adalah ukuran mengenai besarnya efek suatu variabel pada variabel lain besarnya perbedaan maupun hubungan yang bebas dari pengaruh sampel. Menghitung effect size uji - t menggunakan rumus Cohen's (Becker, 2000) $d$ sebagai berikut :

Keterangan

$$
\begin{gathered}
d=\frac{\overline{x_{1}}-\overline{x_{1}}}{S_{g a b}} \\
S_{g a b}=\sqrt{\frac{\left(n_{1}-1\right) S_{1}{ }^{2}+\left(n_{2}-1\right) S_{2}{ }^{2}}{n_{1}+n_{2}-2}}
\end{gathered}
$$

$\overline{x_{1}} \quad=$ Rerata kelompok eksperimen

$\overline{x_{2}} \quad=$ Rerata kelompok kontrol

$n_{1} \quad=$ Jumlah sampel kelompok eksperimen

$n_{2} \quad=$ Jumlah sampel kelomok kontrol

$S_{1}{ }^{2}=$ Varians kelompok eksperimen

$S_{2}{ }^{2}=$ Varian kelompok control 
Hasil perhitungan effect size diinterpretasikan dengan menggunakan klasifikasi menurut Cohen (Becker, 2000) yaitu.

Tabel 6. Klasifikasi Effect Size

\begin{tabular}{|c|c|}
\hline Besard & Interpretasi \\
\hline $0,8 \leq d \leq 2,0$ & Besar \\
\hline $0,5 \leq d<0,8$ & Sedang \\
\hline $0,2 \leq d<0,5$ & Kecil \\
\hline
\end{tabular}

3.

Berdasarkan Berdasarkan Tabel 6 diperoleh nilai $=1,10$. Hal ini menunjukan bahwa pengaruh model pembelajaran kooperatif tipe Think Pair Share (TPS) terhadap peningkatan kemampuan pemecahan masalah matematis siswa di katagori besar yaitu $0,8 \leq 1,01 \leq 2,0$.

2. Analisis Angket Skala Sikap terhadap pembelajaran matematika

Tabel 7. Sikap Siswa Terhadap Pembelajaran Matematika

\begin{tabular}{|r|l|l|l|l|l|l|l|l|l|l|l|l|c|}
\hline \multirow{2}{*}{ No } & Nama & \multicolumn{10}{|c|}{ Pernyataan/ Nomor butir soal } & \multicolumn{2}{c|}{ Jumlah } \\
\cline { 2 - 14 } & Responden & 1 & 2 & 3 & 4 & 5 & 7 & 11 & 12 & 13 & 14 & 17 & Skor \\
\hline 1 & S1 & 4 & 5 & 4 & 4 & 4 & 4 & 4 & 4 & 4 & 5 & 5 & 47 \\
\hline 2 & S 2 & 5 & 4 & 5 & 5 & 5 & 5 & 4 & 4 & 5 & 5 & 5 & 52 \\
\hline 3 & S 3 & 5 & 4 & 5 & 5 & 5 & 5 & 4 & 5 & 5 & 5 & 4 & 52 \\
\hline 4 & S 4 & 5 & 4 & 4 & 5 & 4 & 4 & 4 & 5 & 5 & 4 & 5 & 49 \\
\hline 5 & S 5 & 4 & 2 & 4 & 4 & 4 & 4 & 4 & 4 & 5 & 4 & 4 & 43 \\
\hline 6 & S 6 & 4 & 5 & 4 & 5 & 5 & 5 & 4 & 4 & 4 & 4 & 5 & 49 \\
\hline 7 & S 7 & 4 & 4 & 5 & 4 & 5 & 5 & 4 & 5 & 5 & 5 & 5 & 51 \\
\hline 8 & S 8 & 4 & 5 & 4 & 4 & 5 & 5 & 5 & 4 & 4 & 5 & 5 & 50 \\
\hline 9 & S 9 & 4 & 2 & 5 & 4 & 5 & 4 & 4 & 4 & 4 & 4 & 4 & 44 \\
\hline 10 & S10 & 5 & 4 & 4 & 5 & 5 & 5 & 5 & 4 & 5 & 5 & 5 & 52 \\
\hline 11 & S11 & 4 & 4 & 4 & 4 & 5 & 5 & 4 & 5 & 4 & 4 & 5 & 48 \\
\hline 12 & S12 & 4 & 5 & 4 & 4 & 4 & 4 & 4 & 4 & 5 & 4 & 4 & 46 \\
\hline 13 & S13 & 4 & 5 & 4 & 4 & 5 & 5 & 4 & 4 & 4 & 4 & 4 & 47 \\
\hline 14 & S14 & 4 & 4 & 4 & 5 & 4 & 4 & 4 & 5 & 4 & 5 & 4 & 47 \\
\hline 15 & S15 & 4 & 4 & 4 & 4 & 4 & 4 & 5 & 4 & 5 & 4 & 5 & 47 \\
\hline 16 & S16 & 4 & 4 & 4 & 4 & 4 & 4 & 4 & 5 & 4 & 4 & 5 & 46 \\
\hline 17 & S17 & 4 & 2 & 4 & 4 & 4 & 4 & 4 & 4 & 5 & 4 & 4 & 43 \\
\hline 18 & S18 & 4 & 4 & 4 & 5 & 4 & 4 & 4 & 4 & 4 & 4 & 4 & 45 \\
\hline 19 & S19 & 4 & 4 & 4 & 4 & 4 & 4 & 4 & 4 & 5 & 4 & 4 & 45 \\
\hline 20 & S20 & 4 & 4 & 5 & 4 & 4 & 4 & 4 & 4 & 4 & 4 & 4 & 45 \\
\hline 21 & S21 & 4 & 5 & 5 & 4 & 5 & 4 & 4 & 5 & 4 & 4 & 5 & 49 \\
\hline 22 & S22 & 4 & 4 & 4 & 4 & 5 & 5 & 4 & 5 & 4 & 4 & 4 & 47 \\
\hline
\end{tabular}




\begin{tabular}{|c|l|c|c|c|c|c|c|c|c|c|c|c|c|}
\hline \multirow{2}{*}{ No } & Nama & \multicolumn{10}{|c|}{ Pernyataan/ Nomor butir soal } & Jumlah \\
& Responden & 1 & 2 & 3 & 4 & 5 & 7 & 11 & 12 & 13 & 14 & 17 & Skor \\
\hline 23 & S23 & 4 & 5 & 4 & 4 & 4 & 4 & 4 & 4 & 4 & 4 & 4 & 45 \\
\hline 24 & S24 & 5 & 4 & 5 & 4 & 5 & 4 & 5 & 5 & 4 & 4 & 5 & 50 \\
\hline 25 & S25 & 5 & 5 & 5 & 4 & 5 & 4 & 4 & 4 & 5 & 4 & 5 & 50 \\
\hline 26 & S26 & 5 & 4 & 4 & 4 & 4 & 5 & 4 & 4 & 4 & 4 & 5 & 47 \\
\hline 27 & S27 & 4 & 2 & 5 & 4 & 4 & 4 & 4 & 4 & 4 & 4 & 4 & 43 \\
\hline 28 & S28 & 5 & 5 & 4 & 5 & 5 & 4 & 4 & 4 & 4 & 4 & 5 & 49 \\
\hline 29 & S29 & 4 & 4 & 4 & 5 & 5 & 5 & 5 & 4 & 4 & 4 & 4 & 48 \\
\hline 30 & S30 & 5 & 5 & 5 & 5 & 4 & 4 & 4 & 5 & 4 & 4 & 5 & 50 \\
\hline & Jumlah & 129 & 122 & 130 & 130 & 135 & 131 & 125 & 130 & 131 & 127 & 136 & 1426 \\
\hline & rata- rata & 4.3 & 4.07 & 4.33 & 4.33 & 4.50 & 4.37 & 4.17 & 4.33 & 4.37 & 4.23 & 4.53 & 4.32 \\
\hline
\end{tabular}

Secara umum rata - rata skor siswa nilainya adalah 4,32. Dengan demikian dapat disimpulkan bahwa respon siswa terhadap pembelajaran matematika adalah positif yaitu $3<4,32 \leq 5$.

Tabel 8. Sikap Siswa Terhadap model pembelajaran kooperatif tipe think Pair Share (TPS)

\begin{tabular}{|r|l|c|c|c|c|c|c|c|c|}
\hline \multirow{2}{*}{ No } & Nama & \multicolumn{7}{|c|}{ Pernyataan / Nomor Butir Soal } & \multirow{2}{*}{ Jumlah } \\
\cline { 3 - 8 } & Responden & 6 & 8 & 9 & 10 & 15 & 16 & 18 & Skor \\
\hline 1 & S1 & 5 & 5 & 4 & 5 & 5 & 4 & 5 & 28 \\
\hline 2 & S2 & 4 & 5 & 4 & 4 & 4 & 4 & 4 & 25 \\
\hline 3 & S3 & 5 & 5 & 4 & 4 & 4 & 5 & 4 & 26 \\
\hline 4 & S4 & 4 & 5 & 4 & 5 & 5 & 4 & 4 & 27 \\
\hline 5 & S5 & 4 & 4 & 4 & 5 & 4 & 4 & 4 & 25 \\
\hline 6 & S6 & 4 & 4 & 4 & 4 & 4 & 4 & 4 & 24 \\
\hline 7 & S7 & 4 & 4 & 4 & 5 & 5 & 5 & 5 & 28 \\
\hline 8 & S8 & 4 & 4 & 5 & 4 & 4 & 5 & 4 & 26 \\
\hline 9 & S9 & 4 & 4 & 4 & 4 & 4 & 4 & 4 & 24 \\
\hline 10 & S10 & 4 & 4 & 4 & 5 & 4 & 5 & 5 & 27 \\
\hline 11 & S11 & 4 & 4 & 4 & 4 & 4 & 4 & 4 & 24 \\
\hline 12 & S12 & 4 & 4 & 4 & 5 & 5 & 5 & 4 & 27 \\
\hline 13 & S13 & 5 & 4 & 4 & 5 & 4 & 4 & 5 & 26 \\
\hline 14 & S14 & 5 & 5 & 5 & 4 & 5 & 5 & 5 & 29 \\
\hline 15 & S15 & 4 & 5 & 5 & 5 & 5 & 5 & 4 & 29 \\
\hline 16 & S16 & 5 & 4 & 5 & 4 & 5 & 5 & 5 & 28 \\
\hline 17 & S17 & 4 & 4 & 4 & 4 & 5 & 4 & 5 & 26 \\
\hline 18 & S18 & 4 & 4 & 4 & 4 & 4 & 4 & 4 & 24 \\
\hline
\end{tabular}




\begin{tabular}{|c|l|c|c|c|c|c|c|c|c|}
\hline \multirow{2}{*}{ No } & Nama & \multicolumn{7}{|c|}{ Pernyataan / Nomor Butir Soal } & \multirow{2}{*}{ Jumlah } \\
\cline { 3 - 9 } & Responden & 6 & 8 & 9 & 10 & 15 & 16 & 18 & Skor \\
\hline 19 & S19 & 4 & 4 & 4 & 4 & 4 & 4 & 5 & 25 \\
\hline 20 & S20 & 4 & 4 & 4 & 4 & 4 & 4 & 4 & 24 \\
\hline 21 & S21 & 5 & 4 & 4 & 5 & 5 & 5 & 5 & 28 \\
\hline 22 & S22 & 5 & 5 & 4 & 5 & 4 & 5 & 5 & 28 \\
\hline 23 & S23 & 5 & 4 & 4 & 4 & 4 & 5 & 4 & 25 \\
\hline 24 & S24 & 4 & 5 & 4 & 4 & 4 & 5 & 5 & 27 \\
\hline 25 & S25 & 5 & 4 & 4 & 5 & 4 & 4 & 4 & 25 \\
\hline 26 & S26 & 4 & 4 & 4 & 4 & 4 & 5 & 5 & 26 \\
\hline 27 & S27 & 4 & 5 & 4 & 4 & 4 & 4 & 2 & 23 \\
\hline 28 & S28 & 4 & 4 & 5 & 4 & 4 & 5 & 5 & 27 \\
\hline 29 & S29 & 4 & 5 & 4 & 5 & 4 & 4 & 4 & 26 \\
\hline 30 & S30 & 5 & 5 & 4 & 4 & 4 & 5 & 4 & 26 \\
\hline & Jumlah & 130 & 131 & 125 & 132 & 129 & 135 & 131 & 783 \\
\hline & rata- rata & 4.33 & 4.37 & 4.17 & 4.40 & 4.30 & 4.50 & 4.37 & 4.35 \\
\hline
\end{tabular}

Secara umum rata - rata skor siswa nilainya adalah 4,35. Dengan demikian dapat di simpulkan bahwa respon siswa terhadap model pembelajaran kooperatif tipe Think Pair Share (TPS) adalah positif yaitu $3<4,35 \leq 5$.

\section{KESIMPULAN DAN SARAN}

Berdasarkan analisis data dan temuan yang diperoleh selama menerapkan model pembelajaran kooperatif tipe Think Pair Share (TPS), maka dapat disimpulkan bahwa.

1. Terdapat peningkatan kemampuan pemecahan masalah matematis siswa dengan model pembelajaran kooperatif tipe Think Pair Share (TPS) lebih baik dari pada kemampuan pemecahan masalah matematis siswa dengan pembelajaran ekspositori.

2. Model pembelajaran kooperatif tipe Think Pair Share (TPS) berpengaruh terhadap kemampuan pemecahan masalah matematis siswa.

Saran dalam penelitian ini Model pembelajaran kooperatif tipe Think Pair Share (TPS) dapat dijadikan sebagai alternatif pembelajaran yang menyenangkan karena siswa dapat lebih aktif dan mengemukakan pendapat di depan teman - teman maupun guru. 
BIORMATIKA Jurnal Ilmiah FKIP Universitas Subang Vol. 5 No 01 Februari 2019 ISSN (p) 2461-3961 (e) $2580-6335$

\section{DAFTAR PUSTAKA}

Becker, (2000). Effect Size Measure For Two Independent Groups, Journal: Effect Size Becker.

BNSP, (2006). Standar Isi Untuk Satuan Pendidikan Dasar dn Menengah Standar Kompetensi dan Kompetensi Dasar SMP/MTs. Jakarta: Kementrian pendidikan nasional.

Hartono, (2014). Matematika Strategi Pemecahan Masalah. Yogyakarta: Graha Ilmu.

Sanjaya, (2013). Strategi Pembelajaran Berorientasi Standart Proses Pendidikan. Jakarta: Kencana Prenadamedia Grup.

Sugiyono, (2015). Metode Penelitian Kuantitatif dan R\&D. Bandung: Alfabeta. 